\title{
The energy value of ryegrass and cocksfoot assessed by a slaughter technique with lambs
}

\author{
By R. MILFORD* aND D. J. MINSON* \\ The Grassland Research Institute, Hurley, Berks \\ (Received 7 December 1964-Accepted 3 May 1965)
}

In a comparison of S. 24 ryegrass and S. 37 cocksfoot, Minson, Raymond \& Harris (1960) found that the apparent digestibility of the organic matter in cocksfoot was usually 6 percentage units lower than of that in ryegrass cut on the same day and at a similar stage of growth. The lower digestibility of the cocksfoot might be expected to lead to a lower energy retention, but no direct evidence is available.

Studies with sheep of the utilization for lipogenesis of isocaloric quantities of volatile fatty acids (VFA) have suggested that propionic and butyric acids are used more efficiently than acetic acid (Armstrong \& Blaxter, 1957). Tilley, Deriaz \& Terry ( 1960 ) found that the rumen volatile fatty acids in sheep receiving cocksfoot contained a higher proportion of acetic acid than did those in sheep receiving ryegrass. If the conclusions of the infusion experiments of Armstrong \& Blaxter can be applied to the proportions of VFA produced naturally within the rumen, then the net energy value per unit of digestible nutrients should be higher for ryegrass than for cocksfoot. However, rumen VFA proportions might be a poor indicator of net energy value because of differences in the rate of acid absorption, methane production and heat of fermentation with the two grasses.

The main object of the work reported in this paper was to compare the efficiency of utilization of the digestible nutrients in ryegrass and cocksfoot. This study might have been made in a calorimeter or respiration chamber but these were not available. Energy retention, of two groups of lambs, was therefore determined by a technique involving the slaughter of animals at the beginning and end of the experiment, similar to that described by Mitchell, Kammlade \& Hamilton (1928).

\section{EXPERIMENTAL}

Design

From a group of forty-one lambs, seventeen were slaughtered at the beginning of the experiment and the energy contents of their bodies were determined. The remaining lambs were divided into two groups and given equal quantities of digestible dry matter as cocksfoot or ryegrass. After 7 days, all lambs were slaughtered and the energy contents of their bodies were determined. The energy retained was calculated by subtracting the body energy content of each lamb at the beginning of the experi-

\footnotetext{
* Present address: CSIRO, Division of Tropical Pastures, Lawes, Queensland, Australia.
} 
ment, estimated from the values for the initial slaughter group, from the observed value at the end of the experiment.

\section{Herbages}

First growth S. 24 ryegrass at the ear emergence stage was cut on Io May r960 and dried at $120^{\circ}$. S. 37 cocksfoot at a similar stage of growth was cut 6 days later and dried.

A digestibility experiment was carried out with both grasses. Each was given to three wethers in digestion crates, the experiment comprising a 7 -day preliminary period and a 12-day collection period. The apparent digestibilities of dry matter and energy were determined for both grasses. Calorific values of the feed and faeces were determined with an adiabatic bomb calorimeter as described previously (Grassland Research Institute, 1961). The content of soluble carbohydrate in the grass was determined by the anthrone method as modified by Deriaz (I96r). Nitrogen content was determined by the method of the Association of Official Agricultural Chemists (1955). The mean contents of $\mathrm{N}$ and soluble carbohydrate in the grasses are given in Table I.

\section{Feeding regime}

The dried grass was weighed into sacks containing ro lb cocksfoot dry matter or $9 \cdot 2 \mathrm{lb}$ ryegrass dry matter, and supplying $7 \cdot \mathrm{I}-7 \cdot 2 \mathrm{lb}$ digestible dry matter. Each lamb was fed once daily at 9.00 am for $7 \mathrm{I}$ days. At the beginning of the experiment one sack of grass was allotted to each animal and one-seventh of the sack given each day. A new sack was then allotted. To allow for increased appetite during the trial, the level of feeding was increased to one-sixth and later to one-fifth of a sack daily. The daily rations were not weighed. Uneaten or spilled food was collected from each animal, bulked, dried and weighed weekly.

Table $\mathbf{1}$. Characteristics of the grasses

\begin{tabular}{|c|c|c|c|c|c|c|c|c|}
\hline \multirow[b]{2}{*}{ Grass } & \multirow{2}{*}{$\begin{array}{l}\text { Date } \\
\text { cut }\end{array}$} & \multirow{2}{*}{$\begin{array}{c}\text { Dry } \\
\text { matter } \\
(\%)\end{array}$} & \multirow{2}{*}{$\begin{array}{c}\mathrm{N} \text { in } \\
\text { dry matter } \\
(\%)\end{array}$} & \multirow{2}{*}{$\begin{array}{c}\text { Soluble } \\
\text { carbo- } \\
\text { hydrate in } \\
\text { dry } \\
\text { matter }(\%)\end{array}$} & \multirow{2}{*}{$\begin{array}{l}\text { Gross } \\
\text { energy in } \\
\text { dry matter } \\
(\mathrm{kcal} / \mathrm{g})\end{array}$} & \multicolumn{2}{|c|}{ Digestibility* $(\%)$} & \multirow{2}{*}{$\begin{array}{l}\text { Digestible } \\
\text { energy in } \\
\text { dry matter } \\
(\mathrm{kcal} / \mathrm{g})\end{array}$} \\
\hline & & & & & & Dry matter & Energy & \\
\hline $\begin{array}{l}\text { S. } 37 \\
\text { cocksfoot }\end{array}$ & 16. v. 60 & $18 \cdot 2$ & $2 \cdot 62$ & 7.9 & 4.54 & $72 \cdot 4 \pm 0.2$ & $69 \cdot 5 \pm 0 \cdot 4$ & $3 \cdot 16$ \\
\hline $\begin{array}{l}\text { S. } 24 \\
\text { ryegrass }\end{array}$ & $10 . v .60$ & $21 \cdot 3$ & $2 \cdot 42$ & 18.5 & $4 \cdot 39$ & $77 \cdot 3 \pm 0.1$ & $74.9 \pm 0.3$ & 3.29 \\
\hline
\end{tabular}

\section{Animals}

It was considered desirable that the animals used in this study should be of high growth potential (Ivins, Dilnot \& Davison, 1958). With such animals there appeared to be more likelihood of recording measurable differences between the nutritive values of different herbages, when the differences were small, than with animals of low growth potential. Lambs were therefore used; these were artificially reared under 'wormfree' conditions to minimize any differential effects resulting from parasitic infection in a purely nutritional experiment (Spedding, 1955). 
Suffolk $\times$ Suffolk half-bred lambs were removed from their mothers at about 2 days of age and reared on 69 pints of milk substitute for a period of 4-8 weeks; a proprietary brand of lamb nuts (concentrates) and hay were given ad lib. After weaning, the lambs grazed for 4-ro weeks on high-quality pasture, care being taken to minimize the possibility of infestation by internal parasites. This grazing period ensured that the lambs were adapted to grass feeding before being allocated to their treatment groups.

It was hoped that the total number of lambs reared would be sufficient to allow for the selection of thirty-six experimental animals of uniform weight. However, owing to an extended lambing season and the loss of a number of lambs during rearing, little selection was possible and the range in weight was from $15 \cdot 0$ to $43.3 \mathrm{lb}$.

The lambs were divided into blocks of three lambs of similar body-weight and sex and allocated at random to three groups each containing twelve animals. One group was slaughtered immediately. Five lambs that had not been selected for the three groups were also slaughtered to extend the range of live weight and the number of animals in the initial slaughter group. The remaining two groups received cocksfoot or ryegrass.

\section{Slaughter procedure}

Immediately after slaughter, each lamb was bled and skinned and the internal organs were removed. The blood was collected in a tared plastic bucket and the weight of blood was recorded. The contents of the reticulo-rumen were weighed and samples taken for the determination of dry matter and VFA. The contents of the remainder of the digestive tract were removed, but not weighed or sampled. Each carcass was treated as follows.

Dressed carcass and head. These were weighed immediately after slaughter. Within $\mathbf{1} \frac{1}{2}-2 \frac{1}{2} \mathrm{~h}$ they were frozen and stored at $-23^{\circ}$. The heads and carcasses were weighed while still frozen, and sawn longitudinally into two approximately equal sides. The left sides were chopped into approximately 2 in. squares and ground without thawing through the coarse plate of a Hobart food mincer (model ME 800; Hobart Mfg Co., Hobart Corner, New Southgate, London, N I I). After thorough mixing, this mince was reminced through a plate with $\frac{3}{16}$ in. aperture. After further mixing, the mincing procedure was repeated on approximately one-quarter of this material, using a $\frac{3}{64}$ in. plate. The operation was completed in 10-12 min to minimize changes in moisture content. It was shown in a preliminary study that with this procedure change in moisture content was $<0.3 \%$ (Milford, 1963).

The dressed carcass and head were thus reduced to a finely divided homogenized material. From it, two $300 \mathrm{~g}$ samples were taken for moisture determinations at $100^{\circ}$ in a forced-draught Unitherm oven (Birmingham \& Blackburn Construction Co. Ltd, Armoury Close, Bordesley Green, Birmingham). The remainder of the minced material was put into a tin, sealed and stored at $-23^{\circ}$.

Offal. This fraction included the digestive and respiratory tract, heart, kidneys, liver and hooves. The samples were stored at $-23^{\circ}$. After thawing, the procedure for weighing, mincing, sampling and moisture determination was the same as for 
the dressed carcasses and heads. It was found impossible to mince the cartilaginous tracheal tissues satisfactorily and they were discarded before the offal fraction was minced.

Blood. After weighing, the blood was immediately sampled before it had coagulated. The blood samples (approximately $200 \mathrm{~g}$ ) were taken in tared screw-topped aluminium containers, and dried in these at $100^{\circ}$ for $36 \mathrm{~h}$. The moisture content of the sample was determined, and the dried blood sample was stored in these containers. When required for analysis the samples were ground through a laboratory mill (Christy \& Norris Ltd, Chelmsford, Essex).

Skin and fleece. The skin with fleece was weighed immediately after slaughter, and dried at $100^{\circ}$ for $24 \mathrm{~h}$. After cooling and weighing, each skin with fleece was chopped through a power-driven chaff-cutter. The chopped material was thoroughly mixed, and samples of approximately $200 \mathrm{~g}$ were taken for analysis. These samples were further chopped with hand scissors into approximately $\frac{1}{4}$ in. lengths and were stored in screw-topped waxed cartons.

Calorific values were determined on duplicate dried samples of dressed carcass and head, offal, blood, and skin and wool (Grassland Research Institute 1961). Samples were approximately $\mathrm{I} g$ dry weight.

\section{$V F A$ in rumen liquor}

The proportions of acetic, propionic and butyric acids in the rumen liquor samples from six lambs fed on each of the two grasses were determined by the gas chromatography technique described by Tilley, Canaway \& Terry (1964).

\section{RESULTS}

\section{Lambs slaughtered initially}

The relationships between preslaughter live weight $(X)$ and either empty body weight $\left(Y_{1}\right)$, empty dry-body weight $\left(Y_{2}\right)$ or total body energy $\left(Y_{3}\right)$ of seventeen lambs were calculated and are presented in Table 2 . Individual results have been presented elsewhere (Milford, 1963). These equations were used to predict initial empty body weight, empty dry-body weight, and total carcass energy value, from the initial live weight of each lamb in the experimental feeding groups.

\section{Feeding trial}

All the lambs receiving ryegrass ate well, but difficulty was experienced in getting some of the lambs to eat cocksfoot. Owing to low voluntary intake, three of those lambs given cocksfoot had to be discarded. Since they were all small animals their loss increased the mean initial live weight of the cocksfoot group by I.4 $\mathrm{kg}$ (Table 3 ). One lamb in the ryegrass group died of an unknown cause. 


\section{Live-weight increments}

Mean live-weight increments of lambs receiving S. 24 ryegrass were greater than those of lambs receiving S. 37 cocksfoot, and the difference between means was significant (Table 3 ). Because of the wide range of live weights included in the groups at the beginning of the feeding period (coefficient of variation $19.2 \%$ ) it was thought that it might be necessary to adjust live-weight increments for initial live weight by covariance analysis. It was found, however, that live-weight increments and initial live weights were not correlated $(r=0.077)$ so that the variability in live-weight increments was thus independent of initial live weights. Individual results have been presented elsewhere (Milford, I963).

Table 2. Seventeen lambs slaughtered at the beginning of the experiment. Regression equations of (1) empty body weight $Y_{1},(2)$ empty dry-body weight $Y_{2}$ and (3) total empty body energy content $Y_{3}$ on live weight at slaughter $(X)$

$\begin{array}{ccc}\text { Equationt } & \begin{array}{c}\text { Standard error } \\ \text { of the estimate }\end{array} & \begin{array}{c}\text { Correlation } \\ \text { coefficient }\end{array} \\ \text { (I) } Y_{1}=0.688 X+0.432 & \pm 0.267 & +0.996 * * * \\ \text { (2) } Y_{2}=0.219 X-0.734 & \pm 0.226 & +0.971 * * * \\ \text { (3) } Y_{3}=1255 X-5274 & \pm 1770 & +0.947 * * * \\ * * * P<0.001 . & & \\ +X, Y_{1} \text { and } Y_{2} \text { are expressed in kg, } Y_{3} \text { in kcal. }\end{array}$

\section{Empty body weight increments}

Empty body weight increments were determined by subtracting, from the empty body weight of each lamb at slaughter, the initial empty body weight calculated from equation I (Table 2) and based on values obtained on the initial slaughter group. The values for these increments are presented in Table 3. As with live-weight increment, covariance analysis on initial live weight did not enhance the significance of these results, and the relationship between initial live weight and empty body weight increment was not significant $(r=0.144)$.

The difference in mean empty body weight increment between the two groups of lambs $(\mathrm{I} \cdot 8 \mathrm{~kg}$ ) was greater than the difference in live-weight increments $(\mathrm{I} \cdot 2 \mathrm{~kg})$. The weight of rumen contents (Table 4 ) in lambs receiving S. 37 cocksfoot was significantly greater than that of the lambs receiving S. 24 ryegrass $(P<0.05)$.

\section{Empty dry-body weight increments}

The empty dry-body weight increment of each lamb was determined by deducting from the empty dry weight at slaughter the initial empty dry weight calculated from equation 2 (Table 2); means are presented in Table 3.

The increment in empty dry-body weight of the lambs receiving S. 24 ryegrass was $0.5 \mathrm{~kg}$ greater than that of those receiving S. 37 cocksfoot. The difference was significant $(P<0.05)$. 


\section{Energy retention}

The total energy retention by each lamb was calculated by subtracting, from the total energy content of the body determined at slaughter, the initial energy content calculated from equation 3 (Table 2); means are presented in Table 3 . The observed tendency towards a greater energy retention with ryegrass than with cocksfoot was not significant $(P>0.05)$.

Table 3. Intake of grass, initial live weight, weight gains and energy retention of lambs

(Mean values with their standard errors)

No. of lambs

Dry-matter intake (kg)

Digestible energy intake

(kcal)

Initial live weight $(\mathrm{kg})$

Live-weight gain $(\mathrm{kg})$

Empty body gain (kg)

Empty dry-body gain (kg)

Energy retained (kcal)

Digestible energy retained $(\%)$
S. 37 cocksfoot

9
$59 \cdot 1$
$186500 \pm 3164$
$16 \cdot 8 \pm 0.9$
$12 \cdot 3 \pm 0.43$
$6 \cdot 6 \pm 0.38$
$3 \cdot 0 \pm 0 \cdot 16$
$20600 \pm 1500$
$11 \cdot 0 \pm 0.6$

S. 24 ryegrass

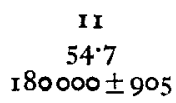

$15.4 \pm 1 \cdot 0$

$13.5 \pm 0.39$

$8 \cdot 4 \pm 0.35$

$3.5 \pm 0.16$

$23900 \pm 620$

$13 \cdot 3 \pm 0 \cdot 6$
Difference Significance of $(\%) \quad$ difference

\begin{tabular}{rl}
\hline 7.4 & - \\
3.4 & - \\
8.3 & NS \\
9.9 & $*$ \\
27.3 & $* *$ \\
16.6 & $*$ \\
16.0 & NS \\
20.9 & $*$
\end{tabular}

NS, not significant; $* P<0.05 ; * * * 0<0$.

Table 4. Weight of rumen contents and concentration and molar proportions of volatile fatty acids in the rumen of lambs at slaughter. Values are means, with standard errors for six lambs receiving each of the grasses

\begin{tabular}{|c|c|c|c|c|c|}
\hline \multirow[b]{2}{*}{ Grass } & \multirow{2}{*}{$\begin{array}{c}\text { Wt of rumen } \\
\text { contents } \\
(\mathrm{kg})\end{array}$} & \multicolumn{3}{|c|}{$\begin{array}{l}\text { Molar proportions of individual fatty acids } \\
\text { in rumen liquor }\end{array}$} & \multirow{2}{*}{$\begin{array}{c}\text { Total } \\
\text { VFA } \\
\text { (m-equiv./ } \\
\text { mil) }\end{array}$} \\
\hline & & $\begin{array}{l}\text { Acetic } \\
\text { acid }\end{array}$ & $\begin{array}{l}\text { Propionic } \\
\text { acid }\end{array}$ & $\begin{array}{l}\text { Butyric } \\
\text { acid }\end{array}$ & \\
\hline $\begin{array}{l}\text { S. } 37 \text { cocksfoot } \\
\text { S. } 24 \text { ryegrass }\end{array}$ & $\begin{array}{l}7 \cdot 39 \pm 0 \cdot 33 \\
6 \cdot 41 \pm 0 \cdot 30\end{array}$ & $\begin{array}{l}7 \cdot 3 \pm 0 \cdot 6 \\
63 \cdot 0 \pm 0 \cdot 6\end{array}$ & $\begin{array}{l}18.6 \pm 0.7 \\
25 \cdot 6 \pm 0.7\end{array}$ & $\begin{array}{r}9 \cdot 6 \pm 0.3 \\
x I \cdot 1 \pm 0.3\end{array}$ & $\begin{array}{l}0.138 \\
0.164\end{array}$ \\
\hline
\end{tabular}

\section{Proportions of VFA in the rumen}

VFA concentrations and proportions were measured in the rumen contents of six lambs receiving ryegrass and six receiving cocksfoot. Ryegrass gave rise to the higher percentage of propionic acid, $25^{\circ} 6$ against $18.6(P<0.01)$, and of butyric acid, II. I against $9 \cdot 6(P<0.05)$, and the lower percentage of acetic acid, 63.0 against $71 \cdot 3(P<0.01)$. With ryegrass the concentration of acid in the rumen was higher, but owing to the lower volume of rumen contents the total quantity of acid present was approximately the same with the two feeds when the samples were obtained at the time of slaughter (Table 4). 


\section{DISCUSSION}

The comparative slaughter technique has been used in previous studies with sheep and cattle (Garrett, Meyer \& Lofgreen, I959; Lofgreen, Bath \& Strong, I963) when, however, the energy contents of the animals were not measured directly but were estimated from the specific gravity of the carcass using published equations and average calorific values of fat and proteins. To eliminate any error associated with the use of published data based on animals different from those used in our experiment, the energy content of all lambs was measured with a bomb calorimeter. This technique only requires simple individual feeding facilities, cold storage, mincer, drying oven and a bomb calorimeter. The slaughter and sample preparation of twenty lambs took six people I day and the mincing of five half carcasses and the internal organs took two people I day.

The live-weight gains of the lambs in this experiment were less than the $0.3 \mathrm{~kg} / \mathrm{day}$ recorded by C. R. W. Spedding (I96I, private communication) for similar lambs at this Institute, which indicates that the gains expressed the full potentials of both grasses at the amounts offered.

Regression equations calculated on an initial slaughter group were used to estimate the initial empty body weight, empty dry-body weight and body energy values of the experimental lambs. Errors are associated with the use of these regression equations, but their practical importance can be minimized by running the experiment for a long period to ensure that the total increment of each measurement is large in relation to the possible error in the initial calculated value.

An important source of error arises from the high variability between animals. The coefficients of variation of the values for live-weight increment, empty body weight increment, empty dry-body weight increment and energy retention were $9.9, \mathrm{r}_{5} \mathrm{I}$, 14.8 and $16.6 \%$, respectively. No information is available to indicate whether the greater variability of the values for empty body weight increment, empty dry-body weight increment and energy retention, compared to those for live-weight increment, was due to increased variability between animals when the results were expressed on the basis of empty weight or to errors associated with the measurement of empty weight. In future experiments of this kind it is probable that lower variability would be obtained if lambs of similar age and initial weight were used.

The errors discussed above had random distributions, and the precision of the technique therefore depended, to a large extent, on the numbers of lambs allocated to each treatment. In this experiment twelve lambs per treatment were sufficient to detect differences between the treatment means in all measurements at the $5 \%$ level of probability, with the exception of energy retention. The difference between means for energy retention was slightly less than that required for significance at $5 \%$.

The lambs given ryegrass ate $3.4 \%$ less digestible energy than those given cocksfoot, but retained $20.9 \%$ more energy. The higher retention could have been caused by one or more of the following factors: ( $I$ ) lower losses of energy as heat of fermentation, as methane and in the urine in lambs fed on ryegrass; (2) a higher efficiency of utilization of the VFA produced in the reticulo-rumen of lambs fed on ryegrass; 
(3) differences between the two grasses in the proportion of the food digested by microbial fermentation in the reticulo-rumen and by enzymes in the lower digestive tract; (4) higher energy requirements of the animals given cocksfoot due to the larger quantities of undigested cocksfoot being passed through the digestive tract.

For the purpose of discussion these points will be considered separately.

Losses of energy as methane and heat of fermentation may have differed for the two herbages. From a theoretical study of rumen fermentation balance, Wolin (rg6o) presented equations which allow methane production and heat of fermentation to be estimated from the proportions of rumen VFA produced. When these equations were applied to the values for the proportions of the acids obtained in this experiment it was estimated that $20.6 \%$ of the energy digested in the rumen appeared as methane with cocksfoot and $17.3 \%$ with ryegrass. The estimated heat of fermentation for both feeds was $6.5 \%$ and was in close agreement with that given for cellulose digestion by Marston (1948). It is of interest to note that the estimated heat of fermentation was independent of the proportions of rumen VFA. The estimated loss of energy per unit of feed energy digested in the rumen was thus $3.3 \%$ higher for cocksfoot than for ryegrass. This is equal to a $2 \%$ higher loss of the total digestible energy if $60 \%$ of the digestion of energy in both feeds occurred in the rumen and if the same quantity of digestible nutrients was given to both groups. These calculations suggest that higher methane loss from cocksfoot could account for some of the difference in energy retention between the two grasses.

In the samples of rumen liquor taken $4^{-6} \mathrm{~h}$ after feeding, the proportion of acetic acid in the rumen VFA of the lambs receiving ryegrass was lower than for those receiving cocksfoot, and the proportions of propionic and butyric acids were higher (Table 4). This may have contributed to the observed difference in utilization of digestible energy, since Armstrong \& Blaxter (1957) have shown that for lipogenesis the efficiency of utilization of isocaloric VFA mixtures is inversely related to the proportion of acetic acid. In addition, Rook (I964) has pointed out that at least half of the intake of metabolizable energy by ruminants is absorbed as VFA.

The utilizations of glucose and protein for lipogenesis are respectively $3 \mathrm{I}$ and $44 \%$ higher when these substances are infused into the abomasum than when they are infused into the reticulo-rumen (Armstrong, Blaxter \& Graham, I960; Martin \& Blaxter, I961). Thus, if the proportion of the energy digested by enzymes in the lower digestive tract was highest for the lambs fed on ryegrass, then the efficiency of utilization of digested energy by these lambs should also be higher. However, since no attempt was made to measure these proportions, the magnitude of their contribution to the observed differences between the energy retention from two grasses is unknown.

The sheep given ryegrass ate $7 \cdot 4 \%$ less dry matter (Table 3 ) and produced $24.0 \%$ less faeces dry matter than those given cocksfoot. It would appear that a smaller quantity of energy must have been used to move this material through the digestive tract, but it is unlikely that this additional work of digestion was sufficient to account for a significant proportion of the lower energy retention from cocksfoot.

In this experiment the digestible energy of ryegrass was utilized more efficiently 
than that of cocksfoot at a similar stage of growth and given in equal amounts. This may have been due to one or more factors, listed on p. 379 , associated with the difference between the energy digestibilities of the two herbages. The values suggest that differences in proportions of VFA produced in the rumen may have been one of the responsible factors. However, it would be unwise to attribute the observed difference between the efficiency of utilization of digestible energy solely to differences in proportions of the acids, or to suggest that such differences in the acids are major factors, without obtaining experimental evidence of a more direct nature.

\section{SUMMARY}

I. A slaughter technique was used to measure energy retention by lambs that were given artificially dried S. 37 cocksfoot or S. 24 ryegrass.

2. The herbages were cut at ear emergence, when the apparent digestibility of the dry matter of the ryegrass was 77 and that of the cocksfoot was $72 \%$. Both grasses were given over a 7I-day period to groups of twelve lambs housed singly in pens. Intakes were adjusted so that each lamb was given daily approximately the same amount of digestible dry matter.

3. At the conclusion of the experiment all the lambs were slaughtered. Energy retention was measured by subtracting from the gross energy values determined at slaughter the initial energy values calculated from a regression of total body energy on live weight. This regression was derived from results obtained from a group of similar lambs slaughtered at the beginning of the experiment.

4. Measurements of the molar proportions of volatile fatty acids in the rumen were made at the time of slaughter. Higher proportions of propionic and butyric acids and a lower proportion of acetic acid were found in the lambs given ryegrass.

5. Of the total digestible energy consumed $\mathrm{I} \cdot \circ \%$ was retained by the lambs receiving cocksfoot and $13.3 \%$ by those receiving ryegrass; this difference was equal to $20.9 \%$ higher retention from ryegrass.

6. It is suggested that the differences in the proportions of rumen VFA may have been one factor contributing to the differences in energy retention. Other factors are discussed.

The helpful encouragement and criticisms of Dr William Davies, Director of The Grassland Research Institute, and of our colleague Mr W. F. Raymond are gratefully acknowledged. Thanks are due to $\mathrm{Mr}$ C. E. Harris and Mr D. E. Williams for technical assistance, to $\mathrm{Mr} \mathrm{E}$. C. Jones for nitrogen, ether extract and ash analyses, and to $\mathrm{Mr}$ R. A. Terry for rumen volatile fatty acid analyses. One of us (R.M.) wishes to thank the CSIRO for granting a 2-year divisional studentship to work at Hurley. 


\section{REFERENCES}

Armstrong, D. G. \& Blaxter, K. L. (1957). Brit. $\mathcal{~ F . ~ N u t r . ~ I x , ~} 4$ I 3.

Armstrong, D. G., Blaxter, K. L. \& Graham, N. McC. (1960). Proc. Nutr. Soc. 19, xxxi.

Association of Official Agricultural Chemists (1955). Official Methods of Analysis, 8th ed. Washington, DC: Association of Official Agricultural Chemists.

Deriaz, R. E. (196r). F. Sci. Fd Agric. I2, I 52.

Garrett, W. N., Meyer, J. H. \& Lofgreen, G. P. (1959). J. Anim. Sci. r8, 528.

Grassland Research Institute (196r). Bull. Commonw. Bur. Past. Fld Crops, no. 45.

Ivins, J. D., Dilnot, J. \& Davison, J. (1958). f. Brit. Grassl. Soc. 13, 23.

Lofgreen, G. P., Bath, D. L. \& Strong, H. T. (r963). F. Anim. Sci. 22, 598.

Marston, H. R. (1948). Biochem. \%. 42, 564.

Martin, A. K. \& Blaxter, K. L. (1961). Proc. Nutr. Soc. 20, vii.

Milford, R. (1963). Herbage digestibility and animal production. PhD Thesis, University of Reading.

Minson, D. J., Raymond, W. F. \& Harris, C. E. (I960). F. Brit. Grassl. Soc. 15, I74.

Mitchell, H. H., Kammlade, W. G. \& Hamilton, T. S. (1928). Bull. Ill. agric. Exp. Sta. no. 3 I4.

Rook, J. A. F. (1964). 7. Brit. Grassl. Soc. I9, roo.

Spedding, C. R. W. (1955). The effects of a sub-clinical worm-burden on the productivity of sheep and the control of parasitism by grazing management. PhD Thesis, University of London.

Tilley, J. M. A., Canaway, R. J. \& Terry, R. A. (1964). Analyst, 89, 363.

Tilley, J. M. A., Deriaz, R. E. \& Terry, R. A. (I960). Proc. int. Grassl. Congr. vir. Reading, p. 533.

Wolin, M. J. (1960). Y. Dairy Sci. 43, 1452. 